\title{
EFFECT OF LIGHTING PROGRAM AND ENERGY LEVEL IN THE RATION ON THE SLAUGHTER TRAITS OF BROILERS
}

\author{
N. Milošević ${ }^{1}$, M. Veljić ${ }^{2}$, M. Đukić Stojčić ${ }^{1}$, L. Perić ${ }^{1}$, S. Bjedov ${ }^{1}$ \\ ${ }^{1}$ University of Novi Sad, Faculty of Agriculture, Department of Animal Science, Trg Dositeja \\ Obradovića 8, 21000, Novi Sad, Republic of Serbia \\ ${ }^{2}$ University of Montenegro, Faculty of Biotechnology, Mihajla Lalića 1, 81000, Podgorica, \\ Montenegro \\ Corresponding author: niko.milosevic@stocarstvo.edu.rs \\ Original scientific paper
}

Abstract: Investigations were carried out to assess the effect of lighting program and energy levels in the diet on carcass characteristics of broilers. The experiment was performed on chickens Cobb 500 hybrids for up to 42 days. The setting was reflected by the principle of two factorial experiments $(2 \times 2)$ at the 40 broiler carcasses of both sexes (10 per replications). The first factor was the lighting program where a group represented by the application of broiler chickens lighting 23L: 1D and group B of the regime 1. wk - 23L: 1D; 2. wk-12L: 12D, 3. wk -14L: 10D; 4. wk - 16L: 8D; 5.wk-18L: 6D, 6. wk -20L: 4D. Another factor was the energy level where meals are in the "A" group were carcasses of broiler chickens fed diets with standard protein and energy in group "B" were the carcasses of chickens fed diets with high energy content to $0.40 \mathrm{ME} \mathrm{MJ} \mathrm{/} \mathrm{kg}$ compared the standard mixtures. Tests have shown that a lighting program and energy level as factors have no significant effect on carcass yield of broiler chickens, but significant differences $(p<0.05)$ emerged as the interaction Axb and Bxa combinations of the parameters "ready to roast" and "ready to grill". The amount of abdominal fat was significantly higher $(\mathrm{p}<0.05)$ in group A and Axb combination compared to Bxa and Bxb. Share weight edible offal expressed as \% of "carcass cut classic " was significantly higher $(\mathrm{p}<0.05)$ in group $B$. The combination of $\mathrm{Axb}$ had a significantly lower proportion of edible offal compared to the combination of Bxa.

Key words: broiler, light, energy level, carcass traits

\section{Introduction}

Broiler chickens are usually grown on a continuous or nearly continuous program of lighting (23 L: $1 \mathrm{D}$ ) in order to increase food intake and their growth 
(Kampo and Davila, 2002). The downside of this is the accumulation of fat in the carcasses, higher incidence of metabolic disorders, and increased occurrence of skeletal deformities (Kristensen et al., 2006; Olanrewaju et al 2006; Onbasilar et al., 2007; Škrbić et al. 2009b, 2012). More research was realized in order to examine different light programs in combination with a protein content and density of the ration for fattening broiler chickens. Tests have shown that, depending on the applied program length lighting can positively and negatively affect the performance of broiler chickens and on carcass quality (Onbasilar et al., 2007; Archer et al., 2009). In addition to continuous lighting there were programs with discontinuous and achemeral light (Li et al., 2007; Škrbić et al., 2009a) and a wide range of light intensity (Blatchford. et al, 2009; Li, et al., 2007, 2010 ).

Diet composition as a factor also is essential for the majority of production parameters. For maximum production and good quality meat, broiler chickens must be provided optimum ratio of protein and energy content of the meal. High-density meals may increase the price of food (Brickett et al., 2007; Kamran et al., 2008; Huang et al., 2009), excretion of nitrogen (Bregendahl et al., 2002), deposition of fat and the incidence of metabolic disorders (Nahashon et al., 2005). Most studies show that feeding high energy meal increases body weight but reduced FCR (Kampo and Davila, 2002; Nahashon et al., 2005; Archer et al., 2009), and produces hulls better conformations (Nahashon al, 2005; Brickette et al, 2007), but significantly higher content of abdominal fat (Sikur et al, 2004; Fan et al., 2008) compared with the low-energy diet. Some researchers suggest that portions of low density will result in lower FCR (Wu et al., 2007; Fanatico et al., 2008), and has no effect on carcass yield, breast meat yield, thigh and abdominal fat (Kamran et al., 2008). Little research has focused on the interaction of light and the energy levels of a meal on production performance and carcass quality of broilers (Buys et al. 1998). Testing was done in order to determine the effect of the length of the light period and the level of energy in food to carcass yield, abdominal fat content and edible offal of broiler chickens.

\section{Materials and methods}

The experiment was performed on chickens Cobb 500 hybrids that were grown in the floor system of holding up to 42 days of age. The tests were carried out two factorial experiments $(2 \times 2)$ with five repetitions per treatment with 20 chicks in each replication. The setting of the experiment is given in the attached schedule.

Treatment

Level of

Program of screen: 23L: 1D - standard factor

A 
Program of screen: I week - 23L: 1D; II - 12L: 12D, III -14L: 10D; IV - 16L: 8D;

V-18L: 6D, VI - 20L: 4D

During the test it has been applied a standard technology for fattening broiler chickens. From the start experiment all relevant production parameters were monitored. Chickens were fed ad libitum. Feeding chickens was with three types of mixtures; starter mixture to 14 days of age that contained $21.22 \% \mathrm{CP}$ and $12.3 \mathrm{MJ} /$ $\mathrm{kg} \mathrm{ME}$ grower to 35 days with a crude protein content of 20.2 and $15.5 \mathrm{MJ} / \mathrm{kg} \mathrm{ME}$ and finisher to this end, with $18.6 \%$ crude protein and $12.7 \mathrm{MJ} / \mathrm{kg}$ of ME. In treatment " $b$ " of the existing content meal added with the oil to increase the energy value of a 0:50 MJ ME / $\mathrm{kg}$ diet. At the end of the trial with 6 weeks of age all birds were measured individually in groups to calculate the averages of groups and then from each experimental group was allocated 10 birds ( 5 male and 5 female) to investigate the slaughter characteristics. Prior to slaughter chickens starved 6 hours, then measured their body weight, then hand-slaughtered carcasses and processed using conventional method.

Data obtained by records of carcass yield parameters, content of abdominal fat and weight of edible offal (liver, heart, stomach, total edible offal) were processed by a computer program STATISTICA 12., identified as average values and variability measures. Performed an analysis of variance (ANOVA), and in the expression of statistical significance in the analysis of variance was applied Duncan test (Duncan Multiple Range Test) at the probability level $\mathrm{p} \leq 0.05$.

\section{Results and Discussion}

Analysis of carcass yield (Table 1) shows that there were statistically significant differences among all treatments and interaction treatment of processing the bodies (KO, SP and SR), which is due to different average body weight of broiler chickens selected sacrificed. This is an indicator that the lighting program and energy content in the diet of chickens factors that significantly affected ( $\mathrm{P}$ $<0.05$ ) on carcass yield in broiler chickens. When it comes to yields as the relative value of the carcass yield, individual treatments (light programs and density meals) had no significant effect, but there were significant spills $(P<0.05)$ interacting with slate SP combination between Axa and BXA. Statistically significant differences $(P<0.05)$ were noted in the SR yield combinations of Axa on the one hand and $\mathrm{BXA}$ and BXB. The available literature in other studies no significant difference in the effect of lighting program yields, but is the impact of the energy value of meals (Brickette et al., 2007; Blatchford et al., 2009; Huang et al., 2009). 
Table 1. Carcass yield and dressing percentage

\begin{tabular}{|l|c|c|c|c|c|c|c|c|c|}
\hline \multirow{2}{*}{ Effect } & \multirow{2}{*}{ Fact. } & \multirow{2}{*}{$\mathrm{N}$} & \multirow{2}{*}{ BW $^{1}$} & \multicolumn{3}{|c|}{ Carcass yield, g } & \multicolumn{3}{c|}{ Dressing percentage, \% } \\
\cline { 5 - 10 } & & & & KO & SP & SR & KO & SP & SR \\
\hline Total & & 40 & 2129 & 1889.6 & 1756.93 & 1583.57 & 82.41 & 76.64 & 67.92 \\
\hline \multirow{2}{*}{ Light } & $\mathrm{A}$ & 20 & 2215 & $1982.5^{\mathrm{b}}$ & $1849.1^{\mathrm{b}}$ & $1672.2^{\mathrm{b}}$ & 82.46 & 76.93 & 68.45 \\
\hline & $\mathrm{B}$ & 20 & 2042 & $1796.7^{\mathrm{a}}$ & $1664.8^{\mathrm{a}}$ & $1494.9^{\mathrm{a}}$ & 82.36 & 76.35 & 67.40 \\
\hline $\begin{array}{l}\text { Density } \\
\text { meal }\end{array}$ & $\mathrm{a}$ & 20 & 2158 & $1935.5^{\mathrm{b}}$ & 1800.7 & 1622.6 & 82.62 & 76.89 & 68.26 \\
\cline { 2 - 10 } $\begin{array}{l}\text { Light } \\
\text { x }\end{array}$ & $\mathrm{b}$ & 20 & 2099 & $1843.7^{\mathrm{a}}$ & 1713.1 & 1544.5 & 82.21 & 76.39 & 67.59 \\
\cline { 2 - 10 } $\begin{array}{l}\text { Density } \\
\text { meal }\end{array}$ & $\mathrm{Axb}$ & 10 & 2210 & $2019.8^{\mathrm{b}}$ & $1885.7^{\mathrm{b}}$ & $1705.7^{\mathrm{b}}$ & 83.09 & $77,61^{\mathrm{b}}$ & $69.19^{\mathrm{b}}$ \\
\cline { 2 - 10 } & $\mathrm{Bxa}$ & 10 & 2220 & $1945.1^{\mathrm{bc}}$ & $1812,4^{\mathrm{bc}}$ & $1638.8^{\mathrm{bc}}$ & 81.83 & 76.26 & 67.71 \\
\cline { 2 - 10 } & $\mathrm{Bxb}$ & 10 & 1979 & $1751.2^{\mathrm{ac}}$ & $1715.8^{\mathrm{ac}}$ & $1539.6^{\mathrm{ac}}$ & 82.14 & $76,17^{\mathrm{a}}$ & $67.33^{\mathrm{a}}$ \\
\hline
\end{tabular}

$a-c$, Means in the same row with different letters are significantly different $(P<0.05) \mathrm{KO}-$ hull conventional tillage; Cup - hull ready to roast; FR - hull ready to grill

${ }^{1}$ Body Weight

Light as a factor of the environment (Table 2) were statistically significant $(\mathrm{P}<0.05)$ to both the absolute and the relative value of fat in carcass yield of broilers, which were confirmed by other researchers (Sikur et al, 2004; Fan et al. 2008). It was expected that the level of energy in the diet significantly influence the content of abdominal fat in carcass however, in this study it has not been confirmed. The reason for this is certainly the high variability in density FAKRA meals ("a" and "b"). The research conducted was in accordance with the research of Wu et al., (2007a), but in contrast to most other studies (Nahashon al, 2005; Brickette et al, 2007; Fanatico et al., 2008). Combinations of AXB and BXA gave a statistically significant difference $(\mathrm{P}<005)$ in the content of abdominal fat in broiler carcasses.

Table 2. Abdominal fat and edible offal

\begin{tabular}{|c|c|c|c|c|c|c|c|c|c|c|c|c|c|}
\hline \multirow[b]{2}{*}{ Effect } & \multirow[b]{2}{*}{ Factor } & \multirow[b]{2}{*}{$\mathrm{N}$} & \multirow[b]{2}{*}{$\mathrm{KO}^{1}$} & \multicolumn{5}{|c|}{ Mass in $g$} & \multicolumn{5}{|c|}{ The share weight of the hull KO,\% } \\
\hline & & & & $\begin{array}{c}\text { Abdo. } \\
\text { fat }\end{array}$ & Liver & Heart & Stomach & $\begin{array}{c}\text { Edibl } \\
\mathrm{e} \\
\text { offal }\end{array}$ & $\begin{array}{c}\text { Abdo. } \\
\text { fat }\end{array}$ & Liver & Heart & Stomach & $\begin{array}{c}\text { Edibl } \\
\mathrm{e} \\
\text { offal }\end{array}$ \\
\hline Total & & 40 & 1889 & 22 & 45 & 10 & 35 & 90 & 1.20 & 2.39 & 0.53 & 1.88 & 4.80 \\
\hline \multirow{2}{*}{ Light } & $\mathrm{A}$ & 20 & 1982 & $24^{\mathrm{b}}$ & 45 & 10 & 35 & 90 & 1.24 & $2.27^{\mathrm{a}}$ & 0.52 & $1.77^{\mathrm{a}}$ & $4.55^{\mathrm{a}}$ \\
\hline & B & 20 & 1796 & 20 & 45 & 9 & 35 & 91 & 1.16 & $2.52^{\mathrm{b}}$ & 0.55 & $2.00^{b}$ & $5.06^{\mathrm{b}}$ \\
\hline \multirow{2}{*}{ Density meal } & $\mathrm{a}$ & 20 & 1935 & 21 & 46 & 10 & 36 & 92 & 1.11 & 2.39 & 0.53 & 1.88 & 4.79 \\
\hline & $\mathrm{b}$ & 20 & 1843 & 23 & 44 & 9 & 34 & 88 & 1.30 & 2.39 & 0.54 & 1.88 & 4.81 \\
\hline \multirow{4}{*}{$\begin{array}{c}\text { Light } x \\
\text { Density meal }\end{array}$} & Axa & 10 & 2019 & 22 & 46 & 10 & 35 & 91 & 1.11 & 2.29 & 0.50 & 1.74 & 4.53 \\
\hline & $\mathrm{Axb}$ & 10 & 1945 & $26^{\mathrm{b}}$ & 43 & 10 & 34 & 89 & $1.38^{\mathrm{b}}$ & $2.25^{\mathrm{a}}$ & 0.54 & 1.79 & $4.58^{\mathrm{a}}$ \\
\hline & Bxa & 10 & 1851 & $20^{\mathrm{a}}$ & 46 & 10 & 37 & 94 & $1.11^{\mathrm{a}}$ & 2.50 & 0.56 & 2.02 & $5.08^{\mathrm{b}}$ \\
\hline & $\mathrm{Bxb}$ & 10 & 1742 & $21^{\mathrm{a}}$ & 44 & 9 & 34 & 88 & 1.210 & $2.54^{\mathrm{b}}$ & 0.54 & 1.97 & 5.05 \\
\hline
\end{tabular}

$a-b$, Means in the same row with different letters are significantly different $(P<0$ 05)

${ }^{1}$ Mass carcass (Traditionally dressed carcass) 
Light program "B" had significantly greater relative weight of the liver, stomach and a relatively larger share of supply of edible offal $(\mathrm{P}<0.05)$. The available literature on the impact of the program lighting values for these parameters is confirmed. The interaction of light meals programs and density in combination $\mathrm{AXB}$ and $\mathrm{BXB}$ showed significant differences $(\mathrm{P}<0.05)$ in the relative weight of the liver and stomach, and combinations composed between AXB and BXA in bulk edible offal (Table 2). These relationships also available literature could not be confirmed nor denied.

\section{Conclusion}

Overall conclusion in the shortest is the length of the light in broilers has a significant effect $(\mathrm{P}<0.05)$ the absolute value of all the carcass yield of broilers tested because of differences in average body weight at the time of sacrificing chickens. The impact of the light program and meals density did not give significant effects on yields of broilers, but the interaction of the light program and meals density combined Axa in relation to the combination of parameter BXA yield of SP was significantly better $(P<0.05)$. The same was the case with the combination of Axa in relation to combination BXA and BXB the parameters in SR $(P<0.05)$. The combination of lighting program $B$ was significantly lower content of abdominal fat in broiler carcasses in relation to the light program A ( $\mathrm{P}$ $<0.05$ ) combinations of light programs and density of meals BXA and BXB had a significantly lower share of abdominal fat in broiler carcasses in relation to the combination of AXB $(\mathrm{P}<0.05)$ light program $\mathrm{B}$ influenced the broiler chickens have a relatively larger mass of the liver and stomach as edible offal compared to the light program A $(\mathrm{P}<0.05)$. Liver weight was significantly greater in the combination of factors in relation to the $\mathrm{BXB}$ bxb and edible offal weight of this combination compared to BXA $(\mathrm{P}<0.05)$.

\section{Acknowledgment}

The study , Effect of lighting program and energy level in the ration on the slaughter traits of broilers " is part of research project TR 31033 financed by the Ministry of Education, Science and Technological Development of the Republic of Serbia. 


\title{
Uticaj svetlosnog programa i nivoa energije u obroku na klanična svojstva brojlera
}

\author{
N. Milošević, M. Veljić, M. Đukić Stojčić, L. Perić, S. Bjedov
}

\section{Rezime}

Istraživanja su izvedena kako bi se procenio učinak svetlosnog programa i nivoa energije $u$ hrani na klanična svojstva brojlerskih pilića. Ogled je izveden na pilićima Cobb 500 hibrida u trajanju do 42 dana. Postavka ogleda je bila po principu dvofaktorijalnog ogleda $(2 \times 2)$ na ukupno na 40 brojlerskih trupova oba pola (po 10 ponavljanja). Prvi faktor je bio program osvetljenja gde su grupu A predstavljali trupovi brojlera iz program osvetljenja $23 \mathrm{~S}: 1 \mathrm{M}$ i grupu B iz režima I ned.- 23S:1M; II - 12S:12M; III - 14S:10M; IV - 16S:8M; V - 18S:6M; VI 20S:4M. Drugi faktor je bio energetski nivo obroka gde su u grupi "a" bili trupovi iz grupe brojlerskih pilića hranjenih smešama sa standardnim sadržajem proteina i energije i u grupi "b" bili trupovi pilića hranjeni smešama sa povećanim sadržajem energije za $0.40 \mathrm{ME} \mathrm{MJ} / \mathrm{kg}$ u odnosu na standardne smeše. Žrtvovani pilići su nasumično odabrani iz ispitivanih grupa mase \pm 1 std. dev. od proseka grupe. Ispitivanja su pokazala da program svetla i gustina obroka kao faktori nemaju značajnog uticaja na randmane klanja brojlerskih pilića, ali su se značajne razlike $(\mathrm{p}<0,05)$ javile kao interakcija kombinacije Axb i Bxa za randmane SP i SR. Količina abdominalne masti bila je značajno veća $(p<0,05)$ grupe A i kombinacija Axb u odnosu na Bxa i Bxb. Udeo mase jetre, želuca i jestivih iznutrica izraženih u $\%$ mase trupa KO bio je statatistički značajno veći $(p<0,05)$ za grupu B. Kombinacija Axb imala je značajno manji udeo jestivih iznutrica u odnosu na kombinaciju Bxa.

\section{References}

ARCHER, G. S., SHIVAPRASAD, H. L. MENCH, J. A. (2009): Effect of providing light on the health, productivity, and behavior of broiler chickens. Poult. Sci. 88:29-37.

BLATCHFORD, R. A., KLASING, K. C. SHIVAPRASAD, H. L. WAKENELL, P. S., ARCHER, G. S., MENCH, J. A. (2009): The effect of light intensity on the behavior, eye and leg health, and immune function of broiler chickens. Poult. Sci. 88:20-28.

BREGENDAHL, K., SELL, J. L. ZIMMERMAN, D. R. (2002): Effect of lowprotein diets on growth performance and body composition of broiler chicks. Poult. Sci. 81:1156-1167. 
BRICKETT, K. E., DAHIYA, J. P., CLASSEN, H. L., GOMIS, S. Influence of Dietary Nutrient Density, Feed Form, and Lighting on Growth and Meat Yield of Broiler Chickens. Poultry Science 86:2172-2181. 2007.

BUYS, N., J. BUYSE, HASSANZADEH-LADMAKHI, M. DECUYPERE, E. (1998): Intermittent lighting reduces the incidence of ascites in broilers: an interaction with protein content of feed on performance and the endocrine system. Poult. Sci. 77:54-61.

CAMPO, J. L. DAVILA, S. G. (2002): Effect of photoperiod on heterophil to lymphocyte ratio and tonic immobility duration of chickens. Poult. Sci. 81:16371639.

FAN, H. P., XIE, M., WANG, W. W., HOU, S. S. HUANG, W. (2008): Effects of dietary energy on growth performance and carcass quality of white growing Peking ducks from two to six weeks of age. Poult. Sci. 87:1162-1164.

FANATICO, A. C., PILIAI, P. B., HESTE, P. Y., FALCONE, C., OWENS, C. M. d EMMERT, J. L. (2008): Performance, livability, and carcass yield of slow-and fast-growing chicken genotypes fed low-nutrient or standard diets and raised indoors or with outdoor access. Poult. Sci. 87:1012-1021.

HUANG, Y., YOO, J. S., KIM, H., WANG, J. Y., CHEN, Y. J., CHO, J. H. KIM, I. H. (2009): Effect of bedding types and different nutrient densities on growth performance, visceral organ weight, and blood characteristics in broiler chickens. J. Appl. Poult. Res. $18: 1-7$.

KAMRAN, Z., SARWAR, M., NISA, M., NADEEM, M. A., MAHMOOD, S. AHMED, S. (2008): Effect of low-protein diets having constant energy-to-protein ratio on performance and carcass characteristics of broiler chickens from one to thirty-five days of age. Poult. Sci. 87:468-474.

KRISTENSEN, H. H., PERRY, G. C., PRESCOTT, N. B., LADEWIG, J., ERSBOLL, A. K. d WATHES, C. M. (2006): Leg health and performance of broiler chickens reared in different light environments. Br. Poult. Sci. 47(3):257263.

LI, W., GUO, Y., CHEN, J., WANG, R., HE, Y., SU, D. ( 2007): Influence of Lighting Schedule and Nutrient Density in Broiler Chickens: Effect on Growth Performance, Carcass Traits and Meat Qualit y. Asian-Aust. J. Anim. Sci. Vol. 20, No. $4: 550-555$.

LI, W., GUO, Y., CHEN, J., WANG, R., HE, Y., DONG-GE, S. (2010): Influence of Lighting Schedule and Nutrient Density in Broiler Chickens: Effect on Growth Performance, Carcass Traits and Meat Quality. Asian-Aust. J. Anim. Sci. Vol. 23, No. $11: 1510-1518$.

NAHASHON, S. N., ADEFOPE, N., AMENYENU, A. D. WRIGHT, D. (2005): Effects of dietary metabolic energy and crude protein concentrations on growth performance and carcass characteristics of French guinea broilers. Poult. Sci. 84:337-344. 
OLANREWAJU, H. A., THAXTON, J. P., DOZIER, W. A., URSWELL, W. B., ROUSH, J. P. BRANTON, S. L. (2006): A review of lighting programs for broiler production. Int. J. Poult. Sci. 5(4):301-308.

ONBASILAR, E. E., EROLL, H., CANTEKIN, Z., KAYA, U. (2007): Influence of intermittent lighting on broiler performance, incidence of tibial dyschondroplasia, tonic immobility, some blood parameters and antibody production. Asian-Aust. J. Anim. Sci. 20(4):550-555.

SIKUR, V. R., ROBINSON, F. E., KORVER, D. R., RENEMA, R. A. ZUIDHOF, M. J. (2004): Effects of nutrient density on growth and carcass traits in fast- and slow-feathering female turkeys. Poult. Sci. 83:1507-1517.

STATSOFT, STATISTICA 12: 2012 Copyright (C) StatSoft. http://www.statsoft.com/

ŠKRBIĆ, Z., PAVLOVSKI, Z., VITOROVIĆ, D., LUKIĆ, M., PETRIČEVIĆ, V. (2009a): The effects of stocking density and light program on tibia quality of broilers of different genotype. Archiva Zootechnica 12:3, 56-63.

ŠKRBIĆ, Z., PAVLOVSKI, Z. LUKIĆ, M. (2009b): Stocking density - factor of production performance, quality and broiler welfare. Biotechnology in Animal Husbandry 25 (5-6), p 359-372.

ŠKRBIĆ, Z., PAVLOVSKI, Z., LUKIĆ, M., PETRIČEVIĆ, V. MILIĆ, D. (2012): The effect of lighting program and type of litter on production and carcass performance of two broiler genotypes. Biotechnology in Animal Husbandry 28 (4), p 807-816.

WU, G., BRYANT, M. M., GUNAWARDANA, P. ROLAND, D. A. (2007) Effect of nutrient density on performance, egg components, egg solids, egg quality, and profits in eight commercial leghorn strains during phase one. Poult. Sci. 86:691697. 